\title{
Satisfaction of Clients by the Service Provision by Burayu City Land Administration and Use Office, Ethiopia
}

\author{
Degu Bekele $(\mathrm{PhD})$ \\ Ethiopian Civil Service University, Addis Ababa, Ethiopia
}

\begin{abstract}
Urban land administration is one of the major services the local government should provide to the people who have interest upon construction of their residential or for other investment purpose. Burayu city is located in Ethiopia, Oromia National Regional State just adjacent to Addis Ababa which is the capital city of the country. Since Burayu city is very proximate to Addis Abeba (than any other urban center in the country) and the suitable feature of the city to live and work in, demand of land for different purpose in the city is very high. The main objective of this study is to recognize the overall satisfaction level of household customers and to identify the major factors determining their satisfaction. This is important as the study is expected to provide a big picture about the satisfaction of households who are customers of the Office of Burayu City Land Administration and Use. It is also expected that the findings of the research will contribute to the expansion of knowledge of service providers and help them to better deal with their members and strive to correct the problems and deliver high quality customer services which in turn can make customers build trust in the office. A random sampling technique was used in drawing the representative samples of the research. The overall satisfaction of customers can be concluded as below the average (3.27) out of 7 which means $46.71 \%$. The mean highest score is registered for tangibility $(4,89)$ followed by 3.38 for assurance, 3.14 for reliability, 3.10 for awareness, 2.59 for responsiveness and the least score is 2.52 for empathy. For this low satisfaction level, the major factors are identified as empathy related factors like the extent to which employees understand the specific needs of customers, understanding and having the best interest of customers at heart, personal attention of employees to customers, and having of convenient operating hours to all its customers.
\end{abstract}

Keywords: Satisfaction, Land Administration, Burayu City, Households

DOI: $10.7176 / \mathrm{JRDM} / 67-03$

Publication date:July $31^{\text {st }} 2020$

\section{Introduction}

Urbanization and urban development in Ethiopia is very recent and the current urbanization level in the country is about $20 \%$ with relatively the highest annual urbanization rate which is about $5 \%$. Urban land administration is one of the major services the local government should provide to the people who have interest upon construction of their residential or for other investment purposes. The decisive role of any government institution is to bring about satisfaction of its customers with services that it is deemed to provide. Services are the production of essentially intangible benefit and experience, either alone or as part of a tangible product through some form of exchange, with the intention of satisfying the needs, wants and desires of the consumers (Mekonnen, 2010). Customer satisfaction by the service is the extent to which a customer recognizes that an entity, firm, a person or an organization has successfully provided a product or service that meets its needs (Federal Democratic Republic of Ethiopia, Ministry of Public Service and Human Resource Development, 2017). Burayu city is one of the urban centers surrounding Addis Abeba, the capital city of Ethiopia. It is very proximate to Addis Ababa than any other urban centers in the country. The main objectives of this study is to recognize the overall satisfaction level of household customers, identify the major factors determining satisfaction and assess the satisfaction of demand side households by the service being provided by the Office of Burayu City Land Administration and Use.

\section{Study Area and Methodology:}

This study is spatially limited to Burayu city which is located just adjacent to Addis Abeba which is the capital city of Ethiopia. It is located about $15 \mathrm{KM}$ from the Office of Addis Ababa City government (located in Piyassa) towards the North West on the way to Ambo immediately outside the city limits of Addis Ababa city (Fig 1). The study is limited to the satisfaction of the demand side households and the satisfaction of the demand side employees in the office is not included. The satisfaction said is limited to the satisfaction of the households by the service being provided by Burayu City Land Administration and Use Office and not by the performances of other sectors in the city or not by the performances of other regional and Federal government. 


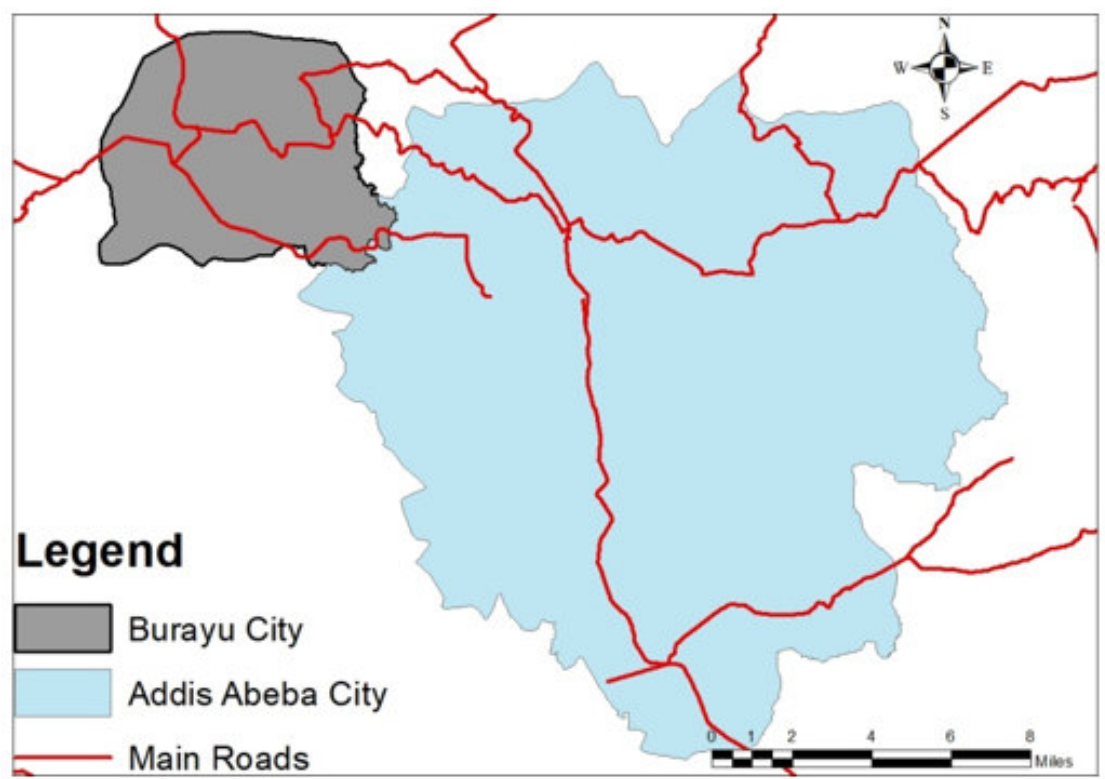

Figure 1: Geographic Location of Burayu City adjacent Addis Abeba

Source, Ethio GIS, supported by own survey, 2019

Because of its proximity to Addis Ababa, its suitability to live and work in and availability of land than its availability in Addis Abeba, demand of land in Buray city is very high and is increasing from time to time. On the other side of the higher demand, supply of land in the city is not satisfactory and the compound of the Office of Burayu City Land Administration and Use is almost always overcrowded by different customers of the office. Customers' satisfaction by the Office of Burayu City Land Administration and Use was seen by the modified SERVIQUAL model comprising twenty five specific areas under six major dimensions. These six dimensions are Tangibility (having five specific areas), Reliability (five specific areas), Responsiveness (four specific areas), Assurance (four specific areas), Empathy (four specific areas) and Awareness (having three specific areas). In the research, the reported responses of the households were used even though the responses may be constructed based on the state of affairs at the time of data collection. service dimensions and customer satisfaction. In this research, the dependent variable is customer satisfaction and the independent variables are the six service dimensions namely tangibility, reliability, responsiveness, assurance, empathy and awareness. Parasuraman et al. (1985) argued that, with minor modification, SERVQUAL can be adapted to any service organization and by referring recent literatures, awareness has been included with five SERVQUAL dimensions.

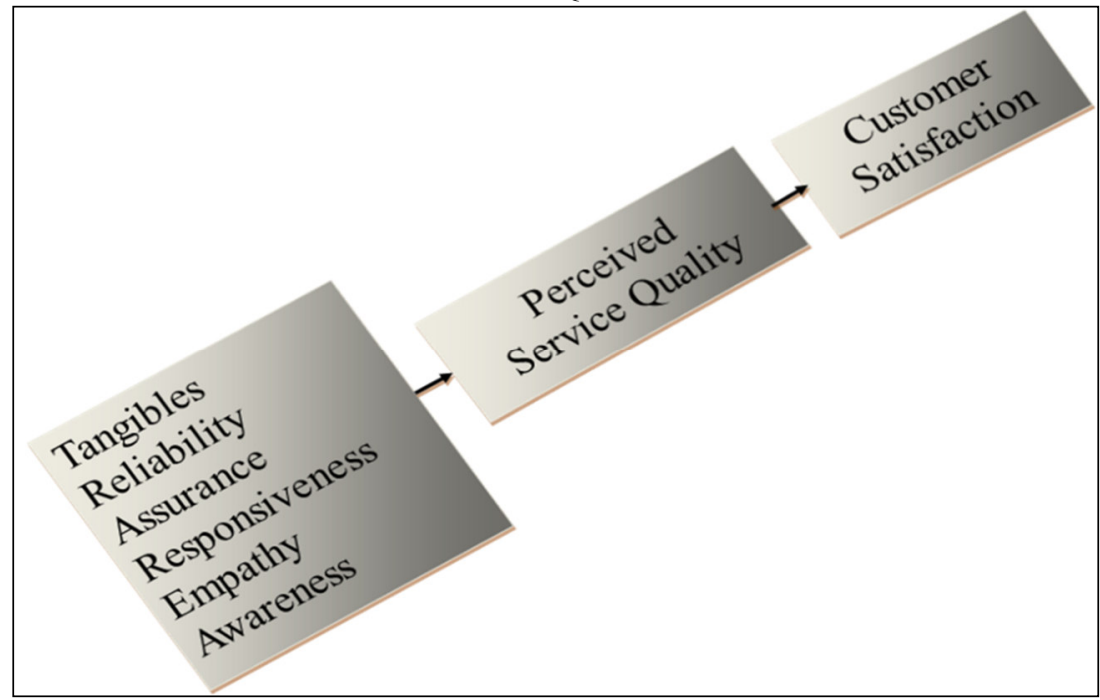

Figure 2: Conceptual Framework of SERVEQUAL Model

Source: Adapted from Gabbie and O’Neill (1996) and Daniel and Berinyuy,(2010).

Considering the nature of the target population which seems to be homogeneous in fulfilling all the requirements to get services from the office, the totality of 286 respondents was taken as the sample size in this research. It is based on population proportion formula with $95 \%$ confidence interval, using the following assumptions and parameters. 


\section{$\frac{\text { Deff } x Z^{2} p(1-p)}{d^{2}}=286$}

Where:

$\mathrm{n}=$ required sample size

$\mathrm{p}=$ proportion of respondents with the population of interest, which is $50 \%$

$1-p=$ the proportion of the remaining population proportion $50 \%$

$\mathrm{Z}=$ Confidence limit, which is usually at $95 \%$ level or 1.96

$\mathrm{d}=$ Margin of error level and usually estimated as $8 \%$ or 0.08 .

Deff $=$ design effect estimated as 1.44

The collected data was coded, edited and tested for reliability using Cronbach Alpha before making any further analysis. The quantitative analysis mainly involves both descriptive statistics such as frequency, percentage, and mean, and inferential statistics, such as correlation, regression and statistical test. The analysis has also employed multiple regressions to anticipate the impact of the quality dimensions i.e,

Satisfaction of the households $=\alpha+\beta_{t} T+\beta_{a s} A s+\beta_{r s} R s+\beta_{r l} R l+\beta_{e} E+\beta_{a w} A w$

Where,

Satisfaction of the households $=$ Satisfaction of customer by Office of Burayu City Land Administration and Use

$\alpha=$ constant

$\beta_{t}, \beta_{a s}, \beta_{r s}, \beta_{r l}, \beta_{e,}$ and $\beta_{a w}=$ Coefficients to estimate Tangibility, Assurance, Responsiveness, Reliability, Empathy and Awareness respectively

$\mathrm{T}$, As, Rs, Rl, E, and Aw = Tangibility, Assurance, Responsiveness, Reliability, Empathy and Awareness respectively

Numbers of different step was taken to ensure the reliability of the study. An alpha Coefficient of reliability tests for the questionnaire has been made under each sub - scale and rearranged until it yields an acceptable result. A reliability coefficient (Cronbach's alpha) of 0.7 or higher is considered "acceptable" in most social science research (Cortina, 1993). In order to achieve validity, the researcher ensured the measuring instrument which provides adequate coverage of the topic by containing adequate representative sample.

\section{Results and Discussion:}

As indicated in the table 1 below, $72.4 \%$ of the sample is male and the remaining 27.6 of the respondents are female.

Table 1: Sample by Gender

\begin{tabular}{|l|l|c|c|}
\hline \multicolumn{3}{|c|}{ Gender of the respondent } & Frequency \\
\hline \multirow{3}{*}{ Valid } & Male & 207 & Percent \\
\cline { 2 - 4 } & Female & 79 & 72.4 \\
\cline { 2 - 4 } & Total & 286 & 27.6 \\
\hline
\end{tabular}

Source, own survey 2019

Out of the total member of the sample, $77.3 \%$ are married or living together with their husband or wife and $17.5 \%$ are never married. The remaining $5.2 \%$ are either divorced or widowed.

Table 2: Sample by Marital Status

\begin{tabular}{|l|c|c|}
\hline Marital Status & Frequency & Percent \\
\hline Married/Living together & 221 & 77.3 \\
\hline Never married & 50 & 17.5 \\
\hline Divorced & 8 & 2.8 \\
\hline Widowed & 7 & 2.4 \\
\hline Total & 286 & 100.0 \\
\hline
\end{tabular}

Source, own survey 2019

The education level of the respondent is shown in table 3 below. It shows that $31.8 \%$ of the respondent has completed senior secondary school, $22.1 \%$ have first degree or above; 21.3 withdrawn from primary school; $14 \%$ have completed college Certificate or diploma and the remaining 10.8\% followed traditional school and can read and write or they are illiterate. 
Table 3: Sample by Education Level

\begin{tabular}{|l|r|r|}
\hline Education Level of the Respondent & Frequency & Percent \\
\hline Illiterate & 9 & 3.1 \\
\hline Traditional/ read and write & 22 & 7.7 \\
\hline Primary school & 61 & 21.3 \\
\hline Senior secondary school & 91 & 31.8 \\
\hline College Certificate or Diploma & 40 & 14.0 \\
\hline 1st degree or above & 63 & 22.1 \\
\hline Total & 286 & 100.0 \\
\hline
\end{tabular}

Source, own survey 2019

Age of $72.4 \%$ of the respondents ranges from 25 years to 45 years. The ages of $10.5 \%$ and of $17.1 \%$ are respectively less than 25 years and more than 45 years.

Table 4: Sample by Age Group

\begin{tabular}{|l|c|c|}
\hline \multirow{2}{*}{ Age Category } & \multicolumn{2}{|c|}{ Respondents } \\
\cline { 2 - 3 } & Frequency & Percent \\
\hline$<25$ & 30 & 10.5 \\
\hline $25-35$ & 106 & 37.1 \\
\hline $36-45$ & 101 & 35.3 \\
\hline $46-55$ & 45 & 15.7 \\
\hline$>55$ & 4 & 1.4 \\
\hline Total & $\mathbf{2 8 6}$ & $\mathbf{1 0 0 . 0}$ \\
\hline
\end{tabular}

Source, own survey 2019

When generally seen from the average of the six dimensions of the modified SERVIQUAL model, satisfaction level of respondents by the Service Being Provided by Office of Burayu City Land Administration and Use is 3.27 which is below the average satisfaction level ( 3.5 out of the seven scale measurement). The mean highest score is registered for tangibility $(4,89)$ followed by 3.38 for assurance, 3.14 for reliability, 3.10 for awareness, 2.59 for responsiveness and the least score is 2.52 for empathy. The next bar graph shows detail of this.

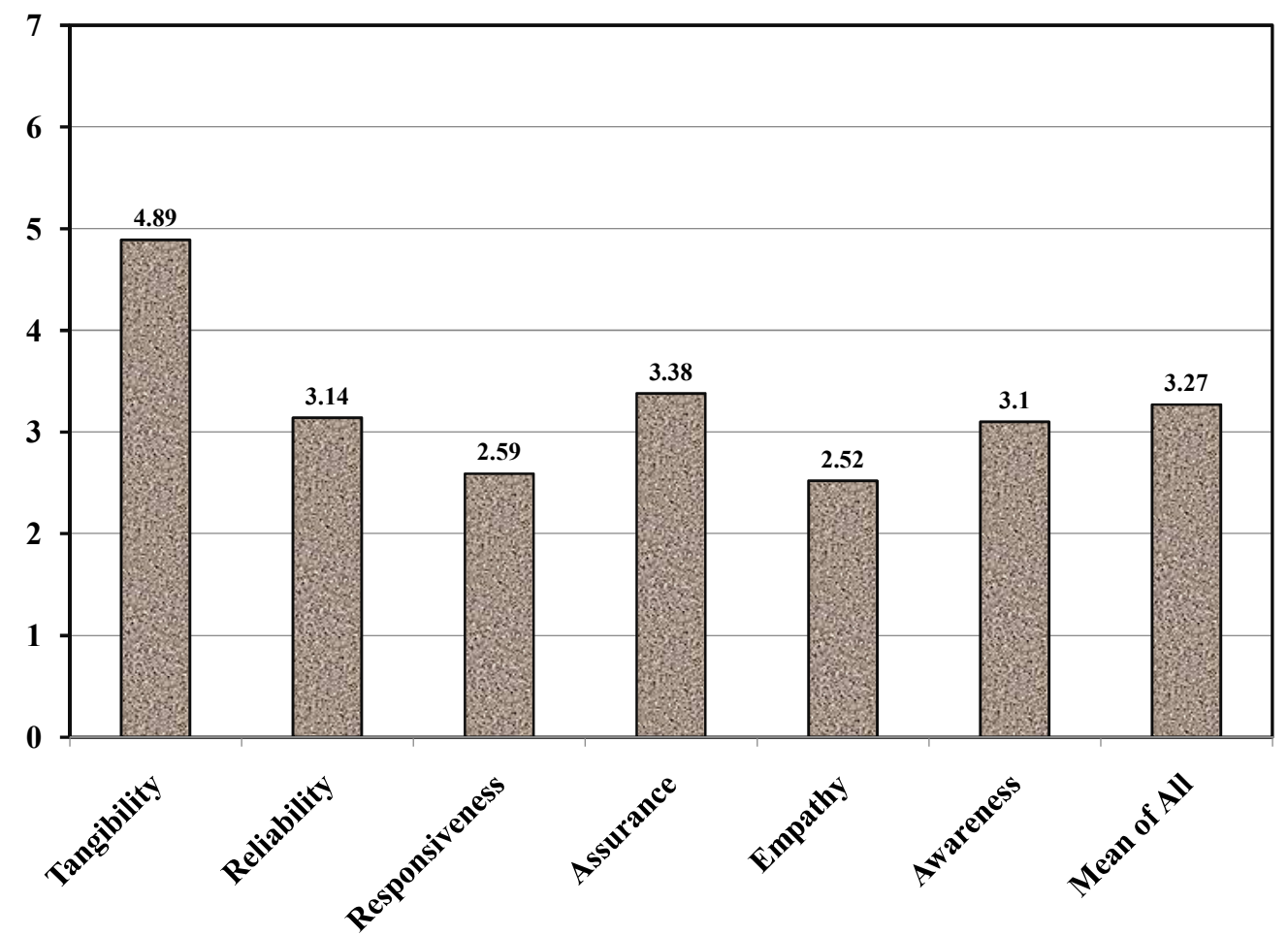

Figure 3: Satisfaction Level of the Respondents by the Six Dimensions Source, Own Analysis, 2019

\subsection{Satisfaction Level of Respondents}

As indicated earlier, SERVIQUAL model to measure satisfaction has five dimensions. To measure the tangibility dimension in this regard, five specific points and the mean for this dimension are presented as follows. Office of 
Burayu City Land Administration and Use's service centers have accessible location (the mean for this is 5.24); Office of Burayu City Land Administration and Use's physical features are appealing (5.07); the Office of Burayu City Land Administration and Use has modern-looking equipment (4.60); the Office of Burayu City Land Administration and Use's reception desk employees appear neat (4.91); and materials associated with the service are visually appealing at Office of Burayu City Land Administration and Use (the mean for this is 4.65). Reliability dimension was also measured against five specific points and the mean for these five are the Office of Burayu City Land Administration and Use performs the service correctly the first time (2.98); when you have a problem, the Office of Burayu City Land Administration and Use shows sincere interest in solving (3.88); the Office of Burayu City Land Administration and Use provides its service at the time it promises to do so (2.83); the Office of Burayu City Land Administration and Use insists on error-free records (3.93); and when the Office of Burayu City Land Administration and Use promises to do something by a certain time, it does (2.10). The third dimension (responsiveness) was measured based on the four specific points rated by the respondents. These are employees in the Land Management Office tell you exactly when the services will be performed (2.56); employees in the Office of Burayu City Land Administration and Use give you prompt service (3.05); employees in the Office of Burayu City Land Administration and Use are always willing to help you (2.44); and employees in the Office of Burayu City Land Administration and Use are never too busy to respond to your request (2.30). The four dimension for Assurance are the behavior of employees in the Office of Burayu City Land Administration and Use instills confidence in you (3.27); you feel safe in your transaction with the Office of Burayu City Land Administration and Use (3.28); employees in the Office of Burayu City Land Administration and Use are consistently courteous with you (3.40); and employees in the Office of Burayu City Land Administration and Use have the knowledge to answer your questions (3.56). To measure Empathy the four areas are the employees of the Office of Burayu City Land Administration and Use understand your specific needs (2.72); the Office of Burayu City Land Administration and Use has your best interest at heart (2.40); the Office of Burayu City Land Administration and Use has employees who give you personal attention (2.54); and the Office of Burayu City Land Administration and Use has operating hours convenient to all its customers (2.43). Fort the Awareness dimension, the mean rate for Office of Burayu City Land Administration and Use aware you about all requirements to get different services is 3.14; for Office of Burayu City Land Administration and Use makes you know on how to appeal decisions is 3.24; and for Office of Burayu City Land Administration and Use aware you about its citizen charter is 2.92. At one statement which says "Over all I am satisfied by the service being provided by Land Management Office of Burayu City" is rated as 3.41.

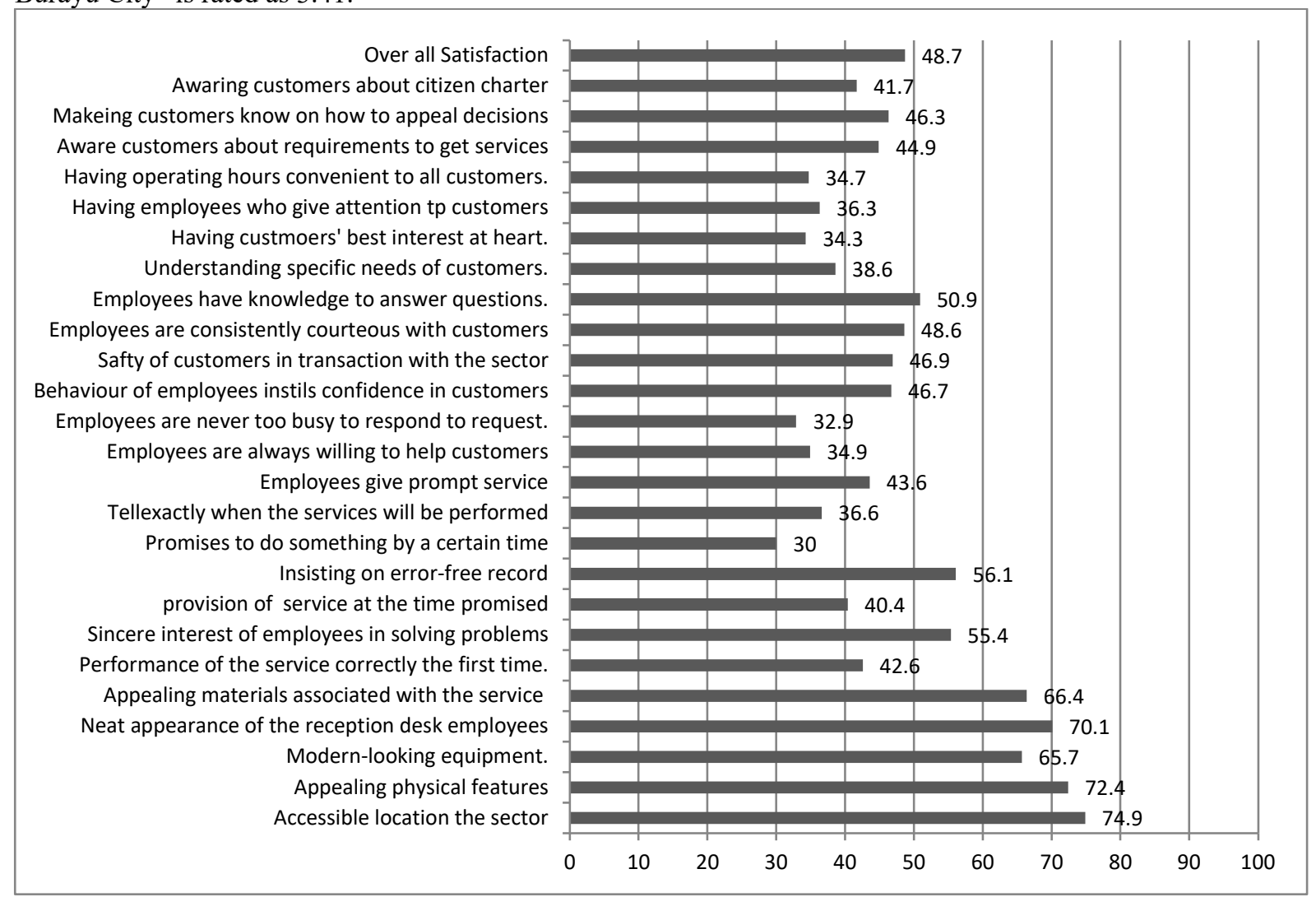

Figure 4: Satisfaction Level of the Respondents by All the Proxies Under the Six Dimensions Source, Own analysis, 2019 


\subsection{Determinants of Customers' Satisfaction}

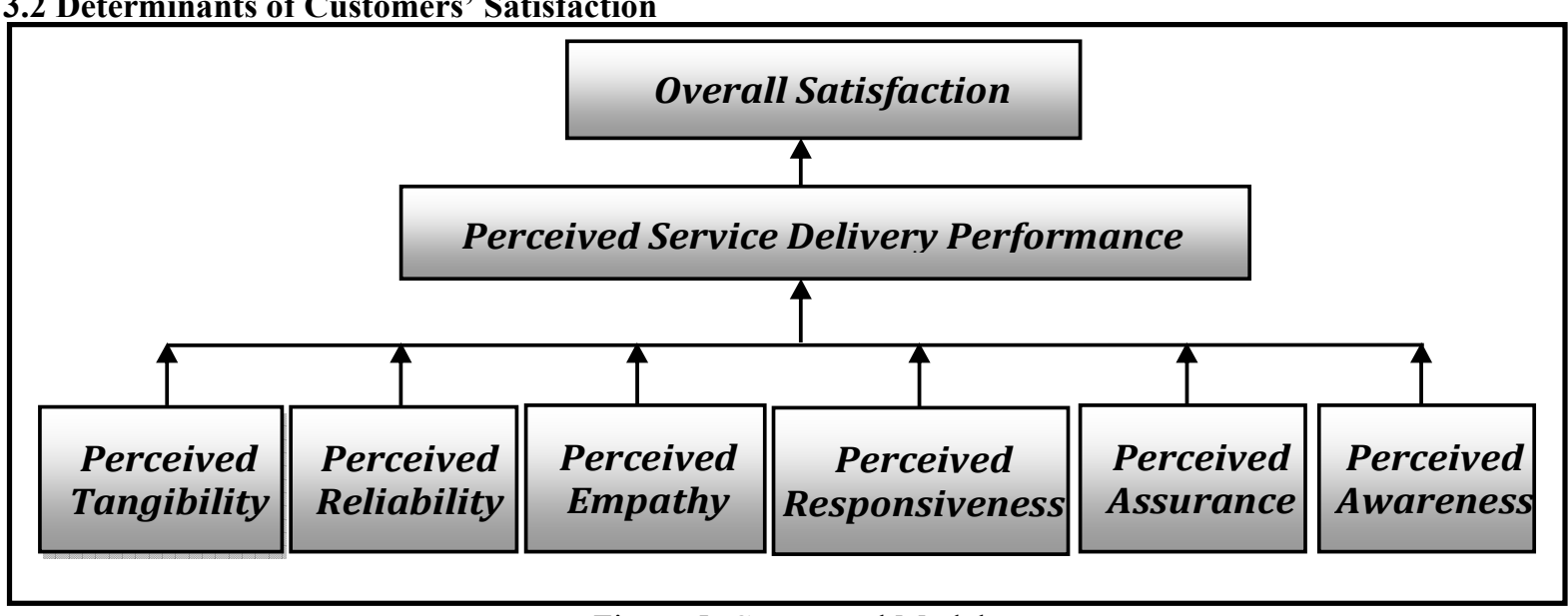

Figure 5: Conceptual Model

Sources: Compiled from related literature

The distribution of the data is neither significantly positively skewed nor significantly negatively skewed with the skewness value which is equal to 0.16 implying that nearly all of the observations are around the expected vale and hence symmetrical and fit to be analyzed statistically. Another assumption about regression is the existence of linear relationship between the variables of interest i.e.

$\mathrm{Y}=\beta 0+\beta 1 \mathrm{X} 1+\beta 2 \mathrm{X} 2+\beta 3 \mathrm{X} 3+\ldots \beta \mathrm{nXn}+\varepsilon$.

In this case, the overall customers' satisfaction is dependent on various factors, such as tangibles, reliability, responsiveness, assurance, empathy and awareness of the customers. This means that the proposed multiple linear regression is logical and fit for the purpose.

The analysis of reliability with the use of Crobach alpha shows as the minimum alpha coefficient is $79.8 \%$, which indicates acceptable level of reliability. There is also no significant correlation among the various independent variables in the model showing that there is no problem of of multi co linearity. This was evidenced by the Value Inflation Factor (VIF) which is equal to 1.32 which is by far less than 10. Moreover, there are also significant relationships between the various dimensions of the service quality and the customers' satisfaction. Pearson Correlation Coefficient between customers 'satisfaction with tangibles, reliability, responsiveness, assurance, empathy and awareness are respectively $0.621,0.591,0.538,0.657,0.580$ and 0.579 showing that all the coefficients shows the data is logical and robust for the purpose.

\subsection{Regression Result for the Customers' Satisfaction}

All the six dimensions (factors) are found to be significant predicators of the customers' satisfaction. With respect to the effect of the independent variables, $65.4 \%$ of the change in the dependent variable (customers' satisfaction in this regard) is explained by the change in those independent variables, in spite of the controlling variables. The other side of this result also shows that $34.6 \%$ of the factors which can explain satisfaction of customers by the service being provided by Office of Burayu City Land Administration and Use is not included in this research. The goodness of model fit is also maintained as the ANOVA is significant at $p<0.01$. The model summary of the regression result is presented below.

Table 5: The General Explaining Power of the Variables

\begin{tabular}{|l|r|r|r|r|r|}
\hline \multicolumn{7}{|c|}{ Model Summary } \\
\hline Model & R & R Square & Adjusted R Square & Std. Error of the Estimate & Sig. F Change \\
\hline 1 & $.809^{\mathrm{a}}$ & .654 & .646 & .293 & .000 \\
\hline
\end{tabular}

a. Predictors: (Constant), Mean of Awareness, Mean of Tangibility, Mean of Empathy, Mean of Assurance, Mean of Reliability, Mean of Responsiveness

Source, Own Analysis, 2019

As can be seen from the table 6 below, in order of the magnitude of their effect, empathy stands first with beta value $(B=0.416, p<.01)$. The next factors are reliability $(B=0.369, p<.01)$, assurance $(B=0.298, p<.01)$, awareness $(B=0.279, p<.01), p<.01)$, tangibles $(B=0.274, p<.01)$ and responsiveness $(B=0.235, p<.05)$ in their order of the magnitude of their effect from the next higher to the lowest. 
Table 6: Power of Determination by Dimensions

\begin{tabular}{|l|c|r|r|r|}
\hline \multirow{2}{*}{ Variables } & \multicolumn{2}{|c|}{ Coefficients } & \multirow{2}{*}{ Sig. } \\
\cline { 2 - 5 } & Beta & Std. Error & & \\
\hline (Constant) & -2.613 & .314 & -8.314 & .000 \\
\hline Mean of Tangibility & .274 & .043 & 6.415 & .000 \\
\hline Mean of Reliability & .369 & .043 & 8.553 & .000 \\
\hline Mean of Responsiveness & .235 & .042 & 5.549 & .000 \\
\hline Mean of Assurance & .298 & .027 & 10.962 & .000 \\
\hline Mean of Empathy & .416 & .042 & 9.798 & .000 \\
\hline Mean of Awareness & .279 & .028 & 9.892 & .000 \\
\hline
\end{tabular}

Source, Own Analysis, 2019

The linear regression equation in this case can be presented as follows.

Customers' Satisfaction

$$
\mathrm{Y}=\beta_{0}+\beta_{1} \mathrm{Em}+\beta_{2} \mathrm{Rl}+\beta_{3} \mathrm{As}+\beta_{4} \mathrm{Aw}+\beta_{5} \mathrm{Ta}+\beta_{6} \mathrm{Rs}+\varepsilon .
$$

Where, $\beta_{0}$ is constant which in this case is equal to $-2.613 ; \beta_{2}$ is beta value for Empathy which in this case is equal to $0.416 ; \beta_{2}$ is beta value for Reliability which is equal to $0.369 ; \beta_{3}$ is beta value for Assurance which is equal to $0.298 ; \beta_{4}$ is beta value for Awareness which is equal to $0.279 ; \beta_{5}$ is beta value for tangibility which is equal to 0.274 ; and $\beta_{6}$ is beta value for Responsiveness which is equal to 0.235. And not that Em, Rl, As, Rs, Ta and Aw in the equation stands respectively for Empathy, Reliability, Assurance, Responsiveness, Tangibles and Awareness. These results clearly indicates that keeping all the other variables constant, a unit increase in the perceived level of empathy, reliability, assurance, awareness, tangibles and responsiveness would have the power of enhancing the customer satisfaction of the Office of Burayu City Land Administration and Use by 0.416, 0.369, 0.298, 0.279, 0.274 and by 0.235 units respectively.

\section{Conclusions}

The overall satisfaction of customers by Office of Burayu City Land Administration and Use can be concluded as below the average (3.27) out of 7 which means $46.71 \%$. The mean highest score is registered for tangibility $(4,89)$ followed by 3.38 for assurance, 3.14 for reliability, 3.10 for awareness, 2.59 for responsiveness and the least score is 2.52 for empathy. For this low satisfaction level, the major factors are identified as empathy related factors like the extent to which employees understand the specific needs of customers, understanding and having the best interest of customers at heart, personal attention of employees to customers, and having of convenient operating hours to all its customers. The other key factor for low customer satisfaction is factors related to reliability like performing the service correctly the first time, showing of sincere interest in solving customers' problems, provision of the service by the office at the time it promises to do so, and insisting on error-free records by the office. In addition, assurance related factors like success of the office in instilling confidence in customers, making customers feeling their transaction with the Land Management Office of the City, consistently courteous of employees with customers, and knowledge of employees to answer customers' questions. Awareness, tangibles and responsiveness related factors are the other factors for the low satisfaction of Customers of the Office of Burayu City Land Administration and Use. $65.4 \%$ of the change in customers' satisfaction is explained by the change in those independent variables. To enhance the satisfaction of their customers, the Office of Burayu City Land Administration and Use should increase the perceived level of empathy, reliability, assurance, awareness, tangibles and responsiveness in the order of their priority (importance). In line with the findings from the regression analysis, all the six factors or dimensions (namely mpathy, Reliability, Assurance, Awareness, Tangibility and Responsiveness) factors are found as influential in terms of driving the customers' satisfaction with the perceived service quality of the Office of Burayu City Land Administration and Use.

\section{Suggestions for Recommendations}

This dimension of the service delivery happens to prevail when the staffs of the office tell customers exactly when certain services will be performed and deliver prompt service, are always willing to help customers and are never too busy to respond to customers' requests. So as to adhere to the service principle of the responsiveness, there shouldn't be one size fits all approach. Customers have to be treated as per their need, not as per the servers' conveniences. All decisions must be customer centered e.g. office hours, choice of payment modalities, and a wider range of pay days.

$\checkmark \quad$ The number of employees should be increased to reduce load from existing ones since they are very loaded and not able to give prompt service due to the fact that the absence of employees on some positions force others to cover additional responsibilities. In this case they can be able to help and respond to customizers' needs.

$\checkmark$ Employees have to be given training related with customer handling to improve their ability of giving error 
free service and instill customers' confidence.

\section{REFERENCES}

- Abtaliana, A., Roza, I.N., and Herlina, s., (2016). Forming customer satisfaction index based on customer perspective in performance management for Tuneeca, a start-up fashion online business, Asia Pacific Institute of Advanced Research (APIAR), Indonesia PP. 120-131 www.apiar.org.au (viewed on 27/08/2018).

- Bitner, M.J. Zeithaml, V.A., Gremler, D.D (2010) Technology impact on the model of service quality Handbook of Service Science (pp.197-218)

- Daniel C.Nand L.P Berinyuy (2010) Using the SERVQUAL Model to assess Service Quality and Customer Satisfaction.An Empirical study of grocery stores in Umea.

- Fornell, Claes. (1992). A National Customer Satisfaction Barometer, The Swedish Experience, Journal of Marketing, January 1992, Volume 56, Number 1.

- Gabbie, O., \& O'Neill, M. (1996). Servqual and the northern ireland hotel sector: A comparative analysis-part 1. Managing Service Quality: An International Journal, 6(6), 25-32.

- Hadiyati, E., (2014) Service quality and performance of public sector: Study on Immigration Office in Indonesia. International Journal of Marketing Studies; Vol. 6, No. 6.

- Ministry of Public Service and Human Resource Development (MoPSHRD), (2017). Citizen satisfaction survey of Ethiopian Public Service Sector, Final Report, Addis Ababa, Ethiopian Civil Service University

- Mekonnen, M. (2010). Assessment of customer satisfaction in transportation service delivery: The case of three terminals of anbassa city bus service enterprise. Ethiopian Journal of Business and Economics, 1(2), 2969.

- Parasuraman, A., Zeithaml, V. A., \& Berry, L. L. (1988). SERVQUAL: A multiple-item scale for measuring consumer perceptions of service quality, Journal of Retailing, Vol. 64, Number 1, p.12-40.

- Parasuraman, ValerieA. Zeithaml, and LeonardL.Berry. Conceptual Model of Service Quality and Its Implications for Future Research, A., Journal of Marketing, Fall 1985, Vol.49, Number 4.

- Prabha Ramseook-Munhurrun,P., Lukea-Bhiwajee,S.D., Naidoo,P., (2010). Service quality in the public service International Journal of Management And Marketing Research, Volume 3 Number 1

- Zeithhaml,ValerieA.(1981)"How Consumer Evaluation Processes Differ Between Goods and Services, in Marketing of Services, J. Donnelly and W. George, eds., Chicago: American Marketing. 